УДК 681.3:658.5

DOI:

Оксана Ісаєва, доктор педагогічних наук, професор кафедри педагогіки та інноваційної освіти

Національного університету “Львівська політехніка", дочент кафедри латинської та іноземних мов Львівського національного медичного університету імені Данила Галищького

Роксолана Алекссєва, студентка групи НОПН-213 Націіонального університету “Львівська політехніка”, вчитель ліцеею № 66 ЛМР

\title{
Е-ПОРТФОЛІО ВЧИТЕЛЯ СЕРЕДНЬОЇ ШКОЛИ ЯК ТЕХНОЛОГІЯ ПРОФЕСІЙНОГО ЗРОСТАННЯ
}

У статті обтрунтовано особливості укладання електронного портфоліо для вчителів загальноосвітніх навчальних закладів. Доведено, щь технологія е-портфоліо сприяє моніторингу професійного зростання вчителя та передбачає не лише фіксацію його старання чи успіхів у визначених видах педагогічної діяльності (виховна робота, викладання, організаторська, позашкільна чи суспільна робота, методична чи науководосліднищька робота), але й активізацію аналітичних здібностей через самостійне зіставлення підсумків своєї діяльності з встановленими стандартними критеріями.

Укладання е-портфоліо дозволяє вирішувати значущі педагогічні завдання: стимулювати мотивацію до педагогічної діяльності і професійного самовиховання, розвивати рефлексивно-оцінні навички вчителів та бажання до самоосвіти. Укладання і використання вчителями технології е-портфоліо у практичній діяльності закладів середньої освіти сприятиме організаџійній, розвивальній, мобілізаційній та інформаційній функиіях.

Ключові слова: е-портфоліо; технологія портфоліо; вчитель; учні; школа; заклади загальної середньоі освіти.

Puc. 2. Лim. 8.

Oksana Isayeva, Doctor of Pedagogical Sciences, Professor of Pedagogy and Innovative Education Lviv Polytechnic National University, Associate Professor of Latin and Foreign Languages Danylo Halytsky Lviv National Medical University

Roksolana Alekseeva, Student of the 21st group, Specialty: educational and pedagogical sciences Lviv Polytechnic National University, Lyceum Teacher No. 66, Lviv city

\section{E-PORTFOLIO OF A SECONDARY SCHOOL TEACHER AS ATECHNOLOGY OF PROFESSIONALADVANCEMENT}

Transformation of secondary school education, shifting the emphasis from academic education to practicaloriented training represents the searching for innovative, more objective tools and technologies for evaluating the results of the teachers' professional activity. E-portfolio is one of such real and fashionable pedagogical technologies demonstrating the personal level of knowledge and professionalism of its owner.

The aim of the article is to substantiate the importance and peculiarities of compiling an e-portfolio for teachers of general secondary educational institutions.

Creating e-portfolio allows teachers to solve important pedagogical tasks: to stimulate motivation for teaching and develop reflective and evaluative skills. The relationship between active systematic formation of e-portfolio and positive dynamics of the parameters of the teachers' professional development, especially its regulatory, motivational and reflective components have been defined. It has been proved that e-portfolio technology helps monitor the teachers' professional growth and educational achievements and involves not only fixing their efforts and success in specific activities, but also activating analytical skills through independent comparison of the results of their activity according to established standard criteria. It has been established that e-portfolio can functionally act as a tool for both analyzing the teachers' educational and professional attainments and predicting their professional future growth.

Compiling of e-portfolio by teachers will promote organizational, developmental, mobilization and information functions in the practical activities of secondary education institutions. The results of the article are considered as a contribution to scientifically grounded ideas concerning using an e-portfolio technology by teachers.

Keywords: e-portfolio; technology of e-portfolio; a teacher; a school; general secondary educational institutions.

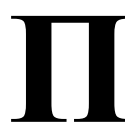
остановка проблеми у загальному вигляді. У системі середньої освіти в Україні відбувається реформа, яка передбачає нові вимоги до світогляду учителя.
Саме тому 22 травня 2018 року МОН затвердило "Положення про Національну освітню електронну платформу”, метою якої є розвиток освіти новітнього змісту: освітні сайти, електронні 
підручники, інтерактивні дошки, інформаційноосвітні портали як оновлені засоби управління навчально-методичним забезпеченням освітнього процесу середньої школи. Особливу увагу необхідно закцентувати на створенні середовища для розвитку електронних освітніх ресурсів та закладенні основ для формування е-компетенції в учнів закладів середньої освіти. Адже “інформатизація освіти $є$ важливою складовою розвитку сучасного суспільства, а створення відкритого навчального середовища та формування його засобів і технологій $\epsilon$ першочерговим завданням оновленої парадигми освіти" [4]. Отож, електронне портфоліо розглядаємо як оновлений прийом формування професійної компетентності вчителя й оригінальну форму самооцінки праці педагога відповідно до Концепції національного освітнього Проєкту “Цифрова школа”.

Актуальність розвідки полягає в тому, що сучасні умови цифровізації вимагають оновленого підходу до моніторингу певних документів учителя, його професійної компетентності в умовах пандемії ковід-19, які вчитель може демонструвати на сторінці е-портфоліо.

Мета дослідження - означити перспективи використання конструктивних ідей щодо оформлення електронного портфоліо вчителя школи закладів середньої освіти.

Відповідно до мети дослідження визначено такі завдання:

1) провести аналіз укладання електронного портфоліо для професійного розвитку вчителів 3 педагогічної точки зору;

2) окреслити і запропонувати можливості укладання електронного портфоліо вчителів закладів середньої освіти.

Аналіз останніх досліджень і публікацій. Електронне портфоліо як наукова проблема досліджується не лише вітчизняними науковцями Л. Варченко-Троценко, А. Дутчак, С. Клімковська, I. Скальська, О.Нижник, алей зарубіжними-П. Абрамі, Б. Волл, П. Елбоу, Дж. Кемпбел, А. Пурвес, Т. Пенні Лайт X. і Чен тощо.

Використання е-портфоліо для підвищення якості організації навчання у закладах середньої освіти та самостійної роботи учнів досліджували науковці Н. Морзе та Л. Варченко-Троценко, які описали використання е-портфоліо в аспекті результативності діяльності педагога. Дослідниця Т. Брунер наголосила на структурних компонентах е-портфоліо. УченіО. Бойко, Н. Ворошилова, Л.Гризун, Д. Золотов, І. Калмикова, С. Коновалова, Х. Подковко досліджували портфоліо як технологію чи інструмент самореалізації, як можливість і перспективу для вчителя тощо. Науковці Н. Василенко, Н. Долінська, В. Загвоздкін, Л. Капуста, С. Копилова, С. Лабудько, С. Мартиненко запропонували власні ідеї щодо важливості і наповнення портфоліо.

Виклад основного матеріалу й обгрунтування отриманих результатів дослідження. Електронне портфоліо (цифрове портфоліо, онлайн-портфоліо, електронне фоліо або ефоліо, еФоліо) [8] - це сукупність електронних доказів, зібраних і керованих користувачем в Інтернеті. Такі електронні докази можуть містити описовий текст, електронні файли, зображення, мультимедіа, записи у блозі та гіперпосилання тощо.

Уважаємо, що портфоліо учителя - це відображення його індивідуального стилю педагогічної діяльності, професійності, унікальності і таланту. Тому визначним для вчителя, роботодавця чи керівника школи є доказова складова портфоліо. Таким чином, укладаючи портфоліо, учитель повинен представити звіт про удосконалення власних навичок, особливості і характер своєї педагогічної діяльності, показати власний творчий та професійний ріст, підтвердити формування навичок рефлексії та бажання навчатися упродовж життя тощо. Тобто, поділяємо думку науковця В. Загвоздкіна [3], який запропонував визначення портфоліо вчителя як “набір матеріалів, що демонструють уміння вчителя вирішувати завдання своєї професійної діяльності, обирати стратегію і тактику професійної поведінки та призначений для оцінки рівня професійності працівника". За складом портфоліо класифікуються на:

- прості - які можуть слугувати як портфоліо документів, портфоліо робіт, або ж портфоліо відгуків. Складаються прості портфоліо, в основному, з двох розділів: розділ документів і робіт, або розділ документів і відгуків, або розділ робіт і відгуків.

- комплексні - які включають описані типи в якості своїх розділів. Укладаються такі портфоліо в трьох розділах: розділ документів, робіт і відгуків.

На нашу думку, найпопулярнішими видами портфоліо вчителя, відповідно до наповнення, вважаються:

1) портфоліо (папка) досягнень - акцент на найкращі доробки вчителя, що підтверджують здобутки в діяльності;

2) рефлексивне портфоліо - охоплює матеріали й оцінку (самооцінку) досягнення цілей, особливості ефективності діяльності 3 
різноманітними джерелами інформації, роздумів, сприйняття чи уявлень;

3) проблемно-дослідницьке портфоліо включає матеріали, які відображають цілі, процес і результат вирішення проблем;

4) тематичне портфоліо - містить матеріал лише в межах однієї тематики;

5) портфоліо-презентація - являє собою підтвердження майстерності вчителя за певними напрямами самоосвіти з метою працевлаштування;

6) портфоліо документації - демонструє професійний розвиток вчителя у формі документів, від теми самоосвіти і до імплементації результатів у практику;

7) представницьке портфоліо - засвідчує педагогічну майстерність за допомогою фото, відео тощо.

Укладаючи портфоліо, педагоги набувають уміння самостійно здобувати, аналізувати, синтезувати й ефективно використовувати інформацію у професійній діяльності. Власне самооцінка і рефлексія - дві фундаментальні характеристики е-портфоліо, що можуть стати мотиваційною основою діяльності педагога і сприяти його особистісному розвитку, стимулюючи до самоосвіти, саморозвитку й удосконалення професійної підготовки. Також пропонуємо схему елементів, що повинні враховуватися при укладанні електронного портфоліо, які представлено на рисунку 1.

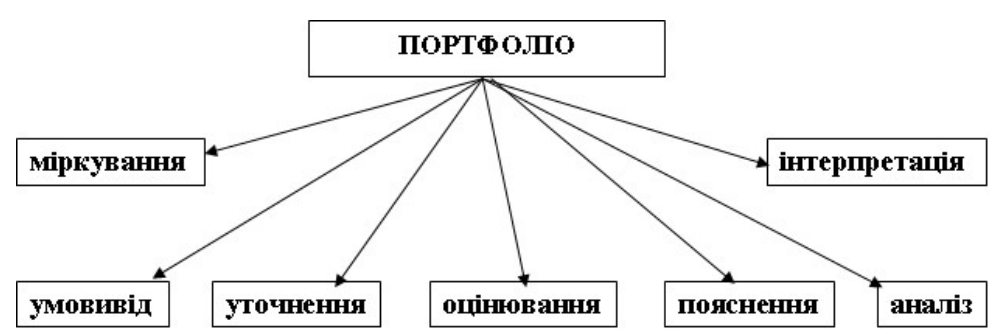

Рис. 1 Схема контенту портфоліо педагога до інформації); часу); учасників).
- функціональність (можливість надавати дані експертам, колегам, керівництву тощо);

- ефективність (швидкість і зручність доступу

- ергономічність (узгодженість 3 вимогами

- доступність (відкритість і прозорість для

Загальновідомо, що електронне портфоліо укладається за допомогою засобів інформаційних технологій і дозволяє власнику підбирати, укладати та структурувати інформацію, представлену в різних форматах (аудіо, відео, графічна інформація, анімація, текст, діаграми графіки тощо). Однак, учитель, створюючи електронне портфоліо, повинен переслідувати і свої власні інтереси, а саме: 1) уможливити простеження прогресування власної фахової і педагогічної діяльності; 2) упорядкувати програми, силабуси, навчальні матеріали і доробки для презентації комісії чи роботодавцю; 3 ) запропонувати прийоми і засоби організації навчального процесу у традиційному чи дистанційному форматі; 4) укласти навчальні матеріали, які можуть бути основою для участі у конкурсах, освітніх платформах та грантових програмах; 5) сприяти розширенню методичного діапазону навчального закладу.

Портфоліо вчителя, зазвичай, формується у папці з файлами. Кожен матеріал, включений до портфоліо, повинен датуватися. Контент портфоліо залежить від конкретних цілей, які ставить перед собою власне учитель. Таким чином, моніторинг професійної діяльності педагога за допомогою е-портфоліо дозволить

вчителю:

- представити правдиві

Науковці Абрамі та Барретт [7] влучно зауважили, що е-портфоліо - це цифровий контейнер, здатний зберігати відео та аудіо записи, включаючи тексти, зображення, відео та звук. У сучасному вимірі е-портфоліо призначені для підтримки різних педагогічних процесів і цілей оцінювання діяльності вчителя, “переосмислення його концептуальних засад, осучаснення змісту освіти та оновлення системи використовуваного методичного інструментарію” $[2,118]$. Беручи до уваги актуальність портфоліо у закладах середньої освіти, необхідно виділити власне переваги електронного портфоліо [1]:

- сучасність (цифровізація освіти);

- оперативність (можливість вносити зміни); результати своєї діяльності і досягнення учнів;

- оцінити власні резерви і потенціал;

- здобути стимул і мотивацію до самовдосконалення протягом життя;

- засвоїти технологію роботи 3 портфоліо 3 позиції учня;

адміністрації:

- здійснювати постійну діагностику результатів праці педагогів;

- сприяти розвитку професійної кар'єри учителів;

- розвивати навички асертивної і рефлексивної діяльності педагогів; педагогів до саморозвитку.
- підтримувати і стимулювати мотивацію 
Уважаємо, що виправдано послуговуватися портфоліо як засобом представлення індивідуальних досягнень вчителя, оскільки цей документ фіксує персональні успіхи з метою реалізації професійного потенціалу і покращання викладацької діяльності. Отож, пропонуємо основні складові електронного портфоліо, що стосуються власного розвитку вчителя, які представлено в діаграмі, рисунок 2 .

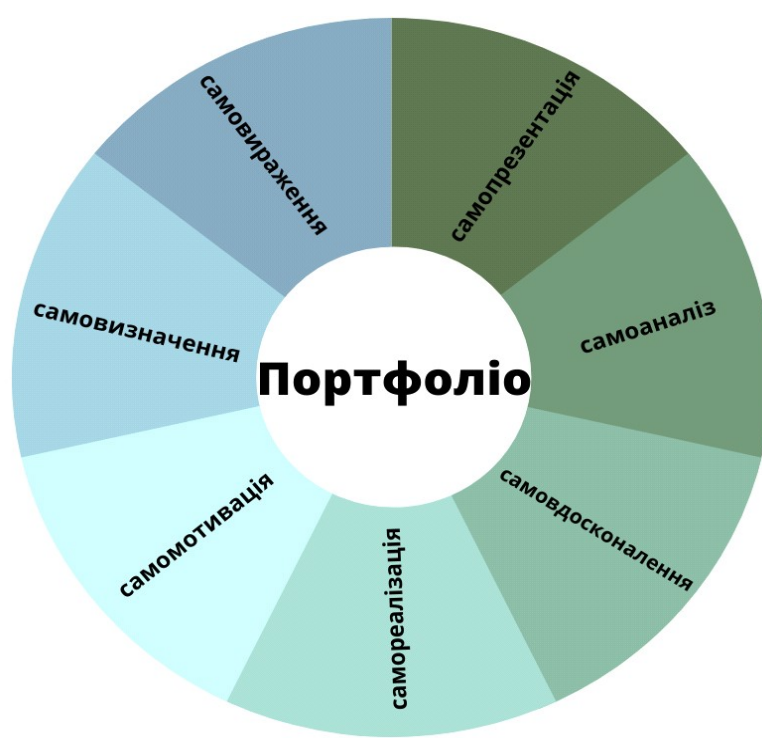

Рис. 2 Діаграма контенту портфоліо педагога

Уважаємо, що метою ведення портфоліо вчителем загальноосвітньої школи $є$ накопичення і систематизація досвіду; чітке означення напрямів розвитку, що сприяє необхідності до самоосвіти або консультування колег чи адміністрації; об'єктивна оцінка професійних компетенцій; допомога в акредитації чи атестації 3 метою одержання вищої категорії, кращої посади, для участі в конкурсі тощо.

Погоджуємося і підтримуємо ідею дослідниці А. Кендюхової [6] щодо чіткості прописаних вимог до оформлення електронного портфоліо та принципів роботи вчителя середньої школи: 1) системність, регулятивність і самомоніторинг; 2) достовірність; 3) об'єктивність; 4) націленість автора на самовдосконалення; 5) структуризація матеріалів, логічність та лаконічність усіх письмових пояснень; 6) акуратність і естетичність оформлення; 7) цілісність, тематична завершеність представлених матеріалів; 8) наочність результатів роботи; 9) технологічність.

Загальновідомо, що портфоліо часто використовують для оцінювання діяльності вчителя середньої школи $з$ двох причин: як для формативного оцінювання, яке проводять 3 метою покращення результатів викладання, так і для підсумкового оцінювання, яке проводиться адміністрацією з метою моніторингу педагогічної діяльності учителя. Фундаментальна відмінність між тими видами оцінювання полягає у наповненні портфоліо, тому дані портфоліо формуються власне для певних видів оцінювання.

Варто зазначити, що автентичне портфоліо учителя справить похвальне враження на роботодавця, засвідчить позитивну тенденцію розвитку для батьків, уможливить представити себе як висококваліфікованого фахівця чи здобути реальну посаду у закладах освіти. Тому особливої уваги заслуговує твердження науковця, що портфоліо - це також інструмент забезпечення моніторингу для подальшого професійного зростання вчителя [5], яке передбачає кожен молодий педагог за умови поєднання глибоких теоретичних знань із практичними навичками.

Власне Нова школа передбачає цифровізацію освіти на усіх її рівнях, опираючись на самомотивацію педагога і стремління до безперервної самоосвіти, доступності навчально-методичних матеріалів, швидкості збирання, передавання чи оновлення інформації та міждисциплінарній інтеграції. Отож, укладаючи портфоліо, кожен учитель повинен усвідомлювати кінцеві цілі, розуміти функції і передбачати форму організації цього документа. Адже за допомогою портфоліо педагог може покращити свою кар'єру, вдосконалити кінцеві результати формування компетентностей в учнів.

Доречно зазначити, що портфоліо не лише формує професійну компетентність учителя середньої школи 3 метою покращення педагогічної діяльності, але й розвиває не менш важливі ㄲi складові як комунікативна, інформаційна, цифрова, предметна, соціальна, загальнокультурна й особистісні якості педагога, тобто відбувається процес формування вчителя як особистості тощо.

Усі розділи портфоліо служать підставою для розгляду і обговорення результатів діяльності вчителя середньої освіти упродовж навчального року на нарадах. Наочність педагогічного продукту, представленого в портфоліо, допомагає встановити зв'язки між попереднім і сьогочасним досвідом, досягненнями, “періодами зростання" і провести моніторинг запланованих результатів практичних навичок учнів.

Уважаємо, що вдало і належно розроблене епортфоліо дозволяє враховувати результати, здобуті вчителем у різноманітних видах діяльності: навчальній, методичній, дослідницькій 
чи суспільній. Також цей документ чітко демонструє вміння учителя вирішувати завдання, які виникають у процесі діяльності, обирати стратегію і тактику професійної поведінки та швидко приймати рішення тощо.

Висновок. При укладанні електронного портфоліо кожен вчитель закладу загальної середньої освіти повинен мати чітко сформульовану мету, проаналізувати документи, які сприяють реалізації обраної тематики, і лише тоді презентувати їх. Тобто, структура і виклад матеріалу е-портфоліо залежить від поставлених завдань та від учителя як особистості, оскільки нема прописаних чітких вимог.

Портфоліо повинно містити як особисті педагогічні ідеї, так і переконливі засоби підтвердження їх ефективності для рейтингу закладу середньої освіти, адже портфоліо можуть використовуватися як технологія під час обговорення результатів діяльності педагога на нарадах; як можливість рефлексії власної діяльності; як документ, у якому представлено професійний розвиток вчителя та уявлення про динаміку результатів педагогічної діяльності i, навіть, реклама школи для батьків.

Перспективу подальших досліджень вбачаємо у формування цифрової компетентност вчителів загальноосвітніх закладів.

\section{ЛІТЕРАТУРА}

1. Бойко О. І. Електронне портфоліо викладача альтернативна форма оцінки його педагогічної діяльності та професіоналізму. Вісник Черкаського державного технологічного університету. № 1.2017. C. $150-154$.

2. Вишківська В., Шикиринська О. Організація процесу навчання в новій українській школі: теоретикопрактичний аспект. Молодь і ринок. № 11 (178). 2019. C. $115-119$.

3. Загвоздкін В. К. Роль портфоліо в навчальному процесі. Деякі психолого-педагогічні аспекти. Педагогічна психологія. № 1.2006. С. 12-13.

4. Ісаєва О. С., Хміляр І. Р. Інформатизація навчального процесу у вищих медичних закладах України. Науковий журнал “Інновачійна педагогіка". Випуск 10. Том 1.2019. С. 149-152.

5. Карандаш М. М. Портфоліо як фактор професійного становлення молодого вчителя. Науковий вісник Мелітопольського державного педагогічного університету. Педагогіка. Мелітополь. № 7. 2011. C. $82-88$.

6. Кендюхова А. А. Професійне портфоліо: територія успіху сучасного педагога: навчально-методичний посібник. Кіровоград: КЗ “КОІППО ім. Василя Сухомлинського”, 2016. 120 с.

7. Abrami P. C., Barrett H. Directions for Research and Development on Electronic Portfolios. Canadian Journal of Learning and Technology 2005. Vol. 31(3). DOI: https:/ /www.cjlt.ca/index.php/cjlt/article/view/26487/19669

8. Zimmerman E. Career couch: Showcasing Your Work, in an Online Portfolio. The New York Times, 2014. DOI: https://www.nytimes.com/2012/07/01/jobs/an-onlineportfolio-can-showcase-your-work-career-couch.html

\section{REFERENCES}

1. Boiko, O. I. (2017). Elektronne portfolio vykladacha - alternatyvna forma otsinky yoho pedahohichnoi diialnosti ta profesionalizmu [Electronic portfolio of a teacher is an alternative form of evaluation of his pedagogical activity and professionalism]. Bulletin of Cherkasy State Technological University. No. 1.pp. 150154. [in Ukrainian].

2. Vyshkivska, O. V. \& Shykyrynska, O. (2019). Orhanizatsiia protsesu navchannia v novii ukrainskii shkoli: teoretyko-praktychnyi aspekt [Organization of the learning process in a new Ukrainian school: theoretical and practical aspect]. Youth and the market. No. 11 (178). pp. 115-119. [in Ukrainian]

3. Zahvozdkin, V. K. (2006). Rol portfolio v navchalnomu protsesi. Deiaki psykholoho-pedahohichni aspekty [The role of the portfolio in the learning process. Some psychological and pedagogical aspects]. Pedagogical psychology. No. 1. pp. 12-13. [in Ukrainian].

4. Isaieva, O. S. \& Khmiliar, I. R. (2019). Informatyzatsiia navchalnoho protsesu u vyshchykh medychnykh zakladakh Ukrainy [Informatization of the educational process in higher medical institutions of Ukraine]. Scientific journal "Innovative pedagogy". Issue 10. Vol. 1. pp. 149152. [in Ukrainian]

5. Karandash, M. M. (2011). Portfolio yak faktor profesiinoho stanovlennia molodoho vchytelia [Portfolio as a factor in the professional development of a young teacher]. Scientific Bulletin of Melitopol State Pedagogical University. Pedagogy. No. 7. pp. 82-88. [in Ukrainian].

6. Kendiukhova, A. A. (2016). Profesiine portfolio: terytoriia uspikhu suchasnoho pedahoha: navchalnometodychnyi posibnyk [Professional portfolio: the territory of success of a modern teacher: a textbook]. Kirovograd, 120 p. [in Ukrainian]

7. Abrami, P. C. \& Barrett, H. (2005). Directions for Research and Development on Electronic Portfolios. Canadian Journal of Learning and Technology. Vol. 31(3). DOI: https://www.cjlt.ca/index.php/cjlt/article/view/26487/ 19669 [in English].

8. Zimmerman, E. (2014). Career couch: Showcasing Your Work, in an Online Portfolio. The New York Times. DOI: https://www.nytimes.com/2012/07/01/jobs/an-onlineportfolio-can-showcase-your-work-career-couch.html [in English].

\section{G58080ल2058080}

